\title{
Verzeichnis
}

\section{der Herren, welche für den zweiundzwanzigsten Band Referate geliefert haben.}

(Die Verantwortlichkeit für den Inhalt der Referate tragen die Herren Referenten. Die in Klammern gesetzten Chiffern bezeichnen die Uebersetzer der in fremder Sprache eingesandten Referate.)

A. Herr Prof. August in Berlin, Bb., Professor $\mathrm{B}$ ob ylew in

Bdn. „ Dr. Brodén in Lund.

Bdt. " Dr. Burkhardt in

Göttingen.

Bm. 》 Prof. v. Braunmühl in

Bö. „ Dr. Börsch in Potsdam.

Br. " Dr Brix in Berlin.

Cly. " Prof. Cayley in Cambridge.

Dn. " Dickstein in Warschau.

Dz. "Prof. Dziobek in Char-

E. \ Prof. G. Enestróm in lottenburg.

Stockholm.

E. K. » Dr. E. Kötter in Berlin.

El. $\gg$ Prof. Engel in Leipzig.

F. $\rightarrow$ Dr. Faerber in Berlin.

F. K. " Dr. F. Kötter in Berlin.

G. " Prof. van Geer in Leiden.

Gbs. , Assist. Prof. Gibs on in

Glr. „ Prof. Glaisher in Cam-

Gr. "Prof. Günther in München.

Gz. 》 Dr. Gutzmer in Berlin.

H. $\quad$ Prof. Hoppe in Berlin.

Hk. " Prof. Hauck in Berlin.

Hn. " Prof. Hensel in Berlin.

Hr. $~$ Prof. Hamburger in Berlin.

Ht. - \ Prof. Hilbert in Königsberg

Hz. „ Prof. Hurwitz in zürich.

Kr. " Prof. Krazer in Strassburg.

Kü. \ Dr. Kühne in Berlin.

La. " Prof. Loria in Genua.

Lbg. " Prof. Lorberg in Bonn.

Lg. " Prof. Lange in Berlin.

Lp. - " Prof. Lampe in Berlin.
Lsg. Herr Dr. L and sberg in Heidelberg.

M. \ Prof. F. Müller in Berlin.

Mh. " Dr. Meth in Berlin.

Mi. " Dr. Michaelis in Berlin.

Mk. \# Prof. Minkowski in Bonn.

Mn. " Prof. Mansion in Gent.

Ms. " Dr. Mestschersky in St. Petersburg.

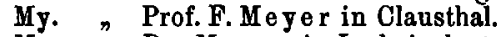

Mz. " Dr. Maynz in Ludwigslust.

No. " Prof. Netto in Giessen.

R. M. , Dr. R. Müller in Berlin.

Sbt. " Dr. Siebert in GrossLichterfelde.

Schi. , Prof. Schlegel in Hagen.

Schn. „ Prof. Schumann in Berlin.

Scht. " Prof.Schubert in Hamburg.

Sfs. " Prof. Schönflies in

Sh. Dr. Schafheitlin in Char-

lottenburg.

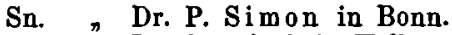

St., Dr. Stäckel in Halle a. $S$.

Std. " Prof. Studnička in Prag.

Sz. " Prof. H. A. Schwarz in

Tn. , Prof. Treutlein in

Berlin.

Karlsruhe.

Tx. $\rightarrow$ Prof. Teixeira in Porto.

V. "Dr. Valentiner in Kopen-

Vi. , Dr. Vivanti in Mantua.

Wbg. " Dr. Wallenberg in Berlin.

Wi." Prof. A. Wassilieff in

Wn. , Prof. Wangerin in Kasan. Halle a. S.

W.St. Prof. W. Stahl in Berlin.

Wz. " Dr. Weltzien in Berlin.

Briefe und Zusendungen erbitten wir entweder durch Vermittelung der Verlagshandlung oder unter der Adresse:

Professor Dr. Lampe, Berlin W, Kurfurstenstr. 139. 